\title{
Understanding tourist mobile hotel booking behaviour: Incorporating perceived enjoyment and perceived price value in the modified Technology Acceptance Model
}

\section{Entendendo o comportamento dos turistas que reservam alojamento através de tecnologia móvel: Incorporando o prazer percebido e o valor percebido no Modelo de Aceitação de Tecnologia modificado}

\author{
Mohamad Amiruddin Mohamad
}

Universiti Teknologi Mara Cawangan Terengganu, Malaysia, amiruddinmohamad@ uitm.edu.my

Salleh Mohd Radzi

Universiti Teknologi MARA, 42300 Puncak Alam, Selangor, Malaysia, salle579@uitm.edu.my

Mohd Hafiz Hanafiah

Universiti Teknologi MARA, 42300 Puncak Alam, Selangor, Malaysia, hafizhanafiah@uitm.edu.my

Received: 24.07.2020; Revisions required: 28.10.2020; Accepted: 08.12.2020

\section{Abstract}

This study examines how mobile technology adoption influences customers' intention to book hotel rooms via smartphone. This study empirically incorporated perceived enjoyment and perceived value in the modified Technology Acceptance Model (m-TAM) and tested it as a unified model. Partial Least Square-Structural equation modelling (PLSSEM) was applied to estimate the proposed research framework based on the survey data collected from 386 travellers who booked hotels via their smartphones. The structural model confirms perceived usefulness, perceived ease of use, perceived enjoyment, and perceived price value significantly influence consumers' behavioural intentions toward mobile hotel booking. This study confirms that TAM can be extended and employed to predict and explain the acceptance of the new technologies in service industries. This study also provides valuable theoretical contributions in developing and testing related theories and practical implications to hotel operators, online travel agencies (OTAs), and hospitality technology suppliers.

Keywords: Mobile hotel booking, Technology Acceptance Model (TAM), perceived enjoyment, perceived price value, mobile booking technology.

\section{Resumo}

Este estudo examina como a adoção da tecnologia móvel influencia a intenção dos clientes de reservar alojamento através de um smartphone. O estudo incorporou empiricamente o prazer percebido e o valor percebido no Modelo de Aceitação de Tecnologia modificado (m-TAM) e testou o mesmo como um modelo unificado. A Modelagem de Equações Estruturais de Mínimos Quadrados Parciais (PLS-SEM) foi aplicada para estimar a estrutura de pesquisa com base nos dados recolhidos de 386 turistas que reservaram hotéis através dos seus smartphones. O modelo estrutural confirma que a utilidade percebida, a facilidade de uso percebida, o prazer percebido e o valor percebido do preço influenciam significativamente as intenções comportamentais dos consumidores em relação às reservas de hotéis por smartphone. Este estudo confirma que o TAM pode ser utilizado para prever e explicar a aceitação das novas tecnologias nas indústrias de serviços. Este estudo também fornece contribuições teóricas valiosas no desenvolvimento e teste de teorias relacionadas e implicações práticas para hotéis, agências de viagens online (OTAs) e fornecedores de tecnologia de alojamento.

Palavras-chave: Reserva de hotel por smartphone, Modelo de Aceitação de Tecnologia (TAM), prazer percebido, valor de preço percebido, tecnologias móveis de reserva.

\section{Introduction}

The mobile phone has brought various changes to the hospitality industry. It has influenced the industry in terms of mobility and the broader reach to facilitate customers to engage in business anytime and anywhere (Kwon, Bae \& Blum, 2013; Ozturk, Nusair, Okumus \& Singh, 2017; Park \& Huang, 2017). Subsequently, the adoption of this technology allows customers to take in a variety of transactions for travel-related products and services, including booking hotel rooms via mobile devices (Ozturk, Bilgihan, Nusair \& Okumus, 2015; Wozniak, Schaffner, Stanoevska-Slabeva \& Lenz-Kesekamp, 2017). According to a report by Dias and Afonso (2020), worldwide mobile travel bookings represent significant value in the tourism market, and hotels remain the sector where smartphone bookings are the most common. However, recent research by Ozturk et al. (2018) stated that customers still prefer to make room reservations using personal computers rather than mobile phones. Correspondingly, a study by Linton and Kwortnik (2015) claimed that if they were using a mobile device, they would use the hotel website rather than using the mobile app for their bookings. Meanwhile, various researchers suggested that mobile booking is the future for travellers (Abu Bakar \& Hashim, 2008; Amaro \& Duarte, 2015; Liang, Schuckert, Law \& Masiero, 2017). Wozniak et al. (2017) stated that understanding the determinants intention of online hotel reservations among the general population should be a priority. Notably, mobile hotel booking has grown and is well accepted by travellers, particularly mature travellers (Park \& Huang, 2017). High usage and acceptance of mobile bookings were observed in developed countries, but not much research has been undertaken within developing countries (Liang et al., 2017; Park \& Huang, 2017). As mobile devices are expected to be one of the leading distribution channels in the hotel industry (Leong, Hew, Ooi, \& Lin, 2019; Rodzi et al., 2016; Park \& Huang, 2017), this study aims to examine how mobile technology influences a customer's intention to book hotel rooms via mobile phone. 


\section{Literature Review}

\subsection{Mobile Booking Technology}

The increasing use of technology towards finding information and conducting online purchase has encouraged hoteliers to adopt mobile booking technology as a part of their hotel distribution channels (Liang et al., 2017; Tao, Nawaz, Nawaz, Butt, \& Ahmad, 2018). However, despite the increasing number of customers using mobile hotel bookings, few researchers suggest a lack of literature on mobile hotel bookings (Ozturk et al., 2017; Liang et al., 2017; Park \& Huang, 2017). Previously, Abdullah, Radzi, Jamaluddin, and Patah (2010), indicated that the influencing factors for the customer to accept mobile hotel bookings are quite broad with limited effort to determine the important attributes. In addition, Wang and Wang (2010) stated that not much attention had been given towards the study of identifying precisely the factor that influences customers' acceptance and usage of mobile in hotel booking despite the growing number of online reservations and wireless mobile activities. Similarly, Ting and Hsu (2013) claimed that the research related to mobile phone's intended use to access hotel service is minimal in past studies. Likewise, Kwan, Bae, and Blum (2013) explained that the hospitality industry survey on mobile phones and mobile applications is limited and scarce.

Only recently, studies on mobile booking acceptance and usage are receiving the researcher's attention. Ozturk et al. (2015) and Ozturk et al. (2017) found that inadequate empirical research focused on the relationship between consumers' preferences and mobile hotel bookings have contributed to the knowledge gap in this field. Other recent studies attempt to shed light on mobile technology acceptance centred on user perception of technology (Chen, Yen, \& Chen, 2009; Fong, Lam, \& Law, 2017; Kim, 2016; Kitcharoen, 2019; Ozturk et al., 2015; Rodzi et al., 2016; Shaw, 2016). Specifically, the researchers focus on perceived ease of use and perceived usefulness (Abdullah et al., 2017; Tao et al., 2018; Yang et al., 2013), compatibility (Chen et al., 2009; Fong et al., 2017; Rodzi et al., 2016), subjective norm (Kim, 2016; Kitcharoen, 2019), trust (Ozturk et al., 2015; Shaw, 2016). Notably, one can reckon that there is still a missing gap in the context of mobile hotel booking study. Given that, it is essential to examine the primary factors of customers' acceptance of mobile hotel booking, mainly on the intention to use the given technology. Wu, Law, and Liu (2018) highlighted the issue of perceived value for money. Moorthy et al. (2017) suggested that it is appropriate to examine the cost factor as it can become a barrier towards people's intention to adopt new technologies such as mobile services. Meanwhile, Nikou and Economides (2015) find that users who have a robust perceived enjoyment can influence their acceptance and usage towards mobile service. On top of that, other researchers also explained that perceived enjoyment could overcome mobile devices' technical limitations as it allows users to access information anytime and anywhere (Abdullah et al., 2017; Fong et I., 2017). Consequently, consumers can be influenced by their enjoyment while using a particular technology (Hussain, Mkpojiogu, \& Yusof, 2016). Similarly, in their research, Yang et al. (2013) suggest that if people can experience enjoyment when using mobile travel booking, it can enhance people to use it even further.

Previously, much relevant research has focused on technology acceptance and, some of the studies are based on various models such as Theory of Reasonable Action (TRA) (Fishbein \& Ajzen, 1975), Theory of Planned Behaviour (TPB) (Ajzen, 1991), the Technology Acceptance Model (TAM) (Davis, 1989) and Unified Theory of Acceptance and Use of Technology (UTAUT) (Venkatesh, Morris, Davis \& Davis, 2003). Among these models, TAM has been extensively applied in the tourism and hospitality industry, particularly in terms of technology adoption (Kim, Park \& Morrison, 2008; Yang, Zhong \& Zhang, 2013; Abdullah, Jayaraman, Shariff, Bahari \& Nor, 2016; Suki \& Suki, 2017). Although TAM has been studied extensively, many studies propose to modify or integrate the current model with other variables to fit different study contexts (Alalwan et al., 2018; Agag \& El-Masry, 2016; Kaushik et al., 2015; Kucukusta et al., 2015). Many studies exclude the attitudinal effect on the TAM model; this study integrates perceived enjoyment and price value in the modified TAM ( $m$-TAM) framework and tests it as a unified model.

\subsection{Technology Acceptance Model (TAM)}

Many researchers used the technology acceptance model (TAM) by Davis (1989) to understand the user's acceptance of new technology. This model was based on the Theory of Reasoned Action (TRA) (Fishbein \& Ajzen, 1975), in which this theory explains how a person's belief may influence their attitude, and from this point, it will develop a behavioural intention to carry out the particular behaviour. The second version of TAM consists of the relationship between external variables: perceived ease of use, perceived usefulness, attitudes (A), and as well as behavioural intention toward the person's actual technology acceptance (Alalwan et al., 2018). Tourism and hospitality researchers adopted TAM to examine the behavioural intention of tourism and hospitality customers towards mobile system technology (Kucukusta et al., 2015; Ozturk et al., 2016; Bhatiasevi \& Yoopetch, 2015; Ko \& Kim, 2011; Murphy, Chen \& Cossutta, 2016; Muñoz, Clement \& Cabanillas, 2017; Suki \& Suki, 2017). Ko and Kim (2011) studied tourism content-based mobile apps and found that perceived ease of use and perceived usefulness positively influence the intention to use mobile apps. A study by Suki and Suki (2017) found a positive relationship between intentions to use a flight ticket booking app on mobile devices. Muñoz et al. (2017) found several variables, such as perceived usefulness towards intention to use, are weak. Another study that uses TAM from the mobile games' perspective found that all variables are significantly influencing behavioural intention to adopt the mobile game (Jiang, Peng \& Liu, 2015; Murphy et al., 2016). These show that TAM is used continuously by researchers to explain which factor influences user acceptance or rejection of mobile application regardless of the field of study. 
However, many studies exclude attitudinal effect while investigating the effect of perceived ease of use and perceived usefulness towards behavioural intention (Ozturk et al., 2016; Bhatiasevi \& Yoopetch, 2015). One of the reasons for excluding attitudinal effects such as perceived enjoyment and perceived price value is that the user's attitude differs based on various internal and external attributes. Since various researchers have widely used TAM in multiple settings, most researchers introduced either extended or new external variables to be used in conjunction with TAM (Abdullah et al., 2017; Tao et al., 2018; Yang et al., 2013). The main reason to add new constructs into TAM is that researchers want to understand better and explain user acceptance of new technology (Hahn, Yoon, \& Kim, 2014). Numerous researchers extended the TAM model by including various attitudinal and non-attitudinal variables in the newly modified model (Abdullah et al., 2017; Tao et al., 2018; Yang et al., 2013). Introducing external variables is vital as these attitudinal and non-attitudinal variables would influence perceived ease of use and perceived usefulness, which is why TAM should be extended (Lee \& Park, 2013). Hence, many external variables have been added, which are perceived information quality (Rodzi et al., 2016; Wang \& Wang, 2010; Wang, Xiang, Law \& Ki, 2016), perceived enjoyment, perceived cost (Hahn, Yoon, \& Kim, 2014) and perceived compatibility (Shatskikh, 2013). Thus, in this study, the researchers integrated perceived enjoyment and price value into the m-TAM framework to examine how these consumer attitudinal variables, besides perceived ease of use and perceived usefulness, would influence tourist behavioural intention in adopting mobile hotel booking.

2.3 Influence of Perceived Ease of Use and Perceived Usefulness on Intention to Use Mobile Hotel Booking

Perceived ease of use and perceived usefulness are the main variables in the Technology Acceptance Model (TAM). Both variables are considered as primary predictors towards behavioural intention to use (Davis, 1989). Perceived ease of use is the degree to which a person believes that using a particular system would be effortless (Davis et al., 1989). Meanwhile, Perceived usefulness is the degree to which a person believes that using a particular system would enhance his or her job performance (Davis et al., 1989). A vast amount of studies shows the significant effect between perceived ease of use and perceived usefulness (Kucukusta et al., 2015; Ozturk et al., 2016; Bhatiasevi \& Yoopetch, 2015). Also, preceding research in the hospitality industry demonstrates the importance of perceived ease of use and perceived usefulness towards the intention to use the technology. Yang et al. (2013) and Morosan (2014), and Suki and Suki (2017) conducted studies towards mobile booking apps in different fields within hospitality concluded that perceived ease of use and perceived usefulness have a direct positive relationship with the intention to adopt the mobile technology. Furthermore, Özbek et al. (2015) and Bhatiasevi and Yoopetch (2015) claim that perceived ease of use and perceived usefulness can explain consumers' behaviour and adoption towards e-booking. Their studies confirm that perceived ease of use has a positive relationship with perceived usefulness in the adoption of mobile booking behaviour. Based on the given justification, the following hypotheses are formulated:

$\mathbf{H}_{1}$ : Perceived ease of use positively influences mobile hotel booking perceived usefulness

$\mathbf{H}_{2}$ : Perceived usefulness positively influences customer behavioural intention to use mobile hotel booking.

$\mathbf{H}_{3}$ : Perceived ease of use positively influences customer behavioural intention to use mobile hotel booking.

\subsection{Influence of Perceived Enjoyment on Intention to Use Mobile Hotel Booking}

Most studies have analysed factors that influence the adoption of mobile applications or services and concluded that enjoyment could positively influence the intention to use a particular technology (Gurtner, Reinhardt \& Soyez, 2014; Hussain et al., 2016). According to Davis et al. (1992), enjoyment is the motivational aspect that influences a person to use new technology, apart from any performance expected from its use. They also added that enjoyment is a significant predictor to predict usage intention. Perceived Enjoyment (PE) refers to the degree in which the activity related to technology usage is perceived as enjoyable in its own way apart from any performance consequences that may be involved. Davis et al. (1992) explained that the user's intention to use the new application is influenced by the development of enjoyment towards the new technology. Many studies found that perceived enjoyment (PE) positively influence the intention to use technology is necessary to influence the intention to adopt mobile commerce (Alalwan et al., 2018; Chin \& Ahmad, 2015; Hussain et al., 2016; Khalid, 2014; Suki \& Suki, 2011). Other researchers use hedonic constructs to reflect perceived enjoyment (PE), a synonym to enjoyment, which they point out that fun can influence the attitude towards usage and intention to use technology (Bruner \& Kumar, 2005; Chen et al., 2009; Fong, Lam, \& Law, 2017). According to Gao, Krogstie, and Siau (2014), individuals with strong personality characteristics usually perceive enjoyment with technology to boost their adaptation and more likely to use mobile services in their daily lives. Therefore, based on the given justification, the following hypotheses are formulated:

$\mathbf{H}_{4}$ : Perceived enjoyment positively influences customer behavioural intention to use mobile hotel booking.

\subsection{Influence of Perceived Price Value on Intention to Use Mobile Hotel Booking}

Prior research had indicated that cost is a constant key factor for consumer usage adoption of online-based hospitality and travel products (Moorthy et al., 2017; Yang et al., 2013; Wu et al., 2018). Wu et al. (2018) stated that cost consists of several aspects such as initial purchase price (mobile phone fee), 
ongoing usage cost (subscription fee, service fee, communication fee), maintenance cost, and the upgrade cost. In the technology acceptance research, cost can be divided into two significant aspects, which are monetary and non-monetary (Kim, Chan, \& Gupta, 2007; Moorthy et al., 2017; Nikou \& Economides, 2015). In marketing research, the price value is frequently defined together with the quality of products or services to determine the perceived value of products or services (Yang et al., 2013; Zhou, Lu \& Wang, 2010; Wang et al., 2016). Venkatesh et al. (2012) stated that technology that offers price value would influence usage intention. Given that mobile hotel reservation apps offer discounts to their users, the apps' usage provides perceived price value to the customers (Özbek et al., 2015; Yang et al., 2013). Based on the given justification, the following hypotheses are formulated:

$\mathbf{H}_{5}$ : Perceived price value positively influences customer behavioural intention to use mobile hotel booking.

\section{Methodology}

\subsection{Research Design}

The descriptive research design was used to explain the relationship between the variables used in this study. According to Sekaran and Bougie (2009), this method can determine and demonstrate the characteristics of interest characteristics. The cross-sectional research design through a quantitative approach was used for this study. An updated report from the Malaysia Comminication and Multimedia Commission (2018) revealed that Malaysian Internet users increased their population from $76.9 \%$ in 2016 to $87.4 \%$ in 2018 . The Internet phenomenon enhanced the mobile and smart phone and consumer preferences in online purchase and booking behaviors (Ajmal, 2017; Goi, 2016). Besides, the majority of the population is exposed to mobile phone daily as these people live in the most urbanised place in Malaysia (Hashim, Mohd Nor \& Janor, 2016). As this research attempts to identify customer intention to adopt mobile hotel booking, the relevant unit of analysis for this research is an individual with experience in mobile hotel booking. Therefore, this study was carried out within the Federal Territory of Kuala Lumpur. The reason to choose Kuala Lumpur as the research setting because it is the most urbanised area in Malaysia (Ali \& Abdullah, 2012; Department of Statistics Malaysia, 2017).

\subsection{Sample Size}

This study utilised the Smith (2013) equation for sample size with an unknown population number. According to Albers (2017), confidence intervals typically range between $90 \%$ and $95 \%$ level for social sciences research. Based on the sample size calculation, the minimum sample size is 384 respondents. The calculated sample size $(\mathrm{N}=384)$ is similar to Krejcie and Morgan (1970) sample size table if the population is above $1,000,000$. This study utilised purposive sampling method. This sampling method is supported by Kumar et al. (2013) and Hill (1998), as they stated that it provides researchers with the justification to make a generalisation from their sample. For the researchers, it helps them to collect the data faster, flexible, and effective. Meanwhile, respondents can answer the questionnaire according to their convenience.

\subsection{Research Instrument}

The questionnaire structurally used two languages, English and Malay as the mediums of communication. There are three sections within the designed questionnaire. Section A was designed to seek respondents' perceived usefulness, perceived ease of use, perceived enjoyment, and price value of mobile hotel booking. The instruments were adopted from Khalid (2014), Huang et al. (2007), and Suki and Suki (2017). For section $B$, the instruments examine respondents' behavioural intentions towards mobile hotel booking. The instruments were adopted from Suki and Suki (2017) and used to measure their behavioural intention. They are measured using Five Point Likert Scales that ranges from "Strongly Disagree" (1) to "Strongly Agree" (5). Meanwhile, Section C assessed the respondents' demographic profile.

To ensure the reliability and validity of the survey instruments, the researcher conducted a pilot test to confirm the research instruments' validity and reliability (Hair, Money, Samouel \& Page, 2007). A total number of 30 respondents were selected for the pilot study. Before executing the pilot test, the instrument validity was established through a panel of experts that involving five academicians. The outcome of this process confirmed that no items need to be eliminated as all items are feasible and appropriate for this research. Additionally, a reliability test was used to test the internal consistency of the questionnaire. As the Cronbach Alpha value is within 0.73 to 0.91 (>.70), overall, it is safe to assume that the items are reliable and acceptable for further analysis.

\subsection{Data Collection and Analysis}

The data are collected using self-administered structured questionnaires. The survey utilised the Google Form platform to collect the data, and it was distributed based on the snowball effect through Facebook, WhatsApp, and e-mail. The data collection process took two months to be completed. The data obtained from the survey were analysed using Statistical Package for the Social Sciences (SPSS) version 23. After data administering and cleaning, the survey data was processed using Partial Least Square-Structural Equation Modelling (PLSSEM) procedures via the SmartPLS 3.1 software.

\section{Data Analysis and Findings}

\subsection{Demographic Profile}

A total of 551 surveys was collected. The data cleaning process was conducted to ensure that the data is consistent and valid for the study. Accordingly, only 386 questionnaires were validated to be processed in SPSS. Overall, the response rate is 77 per cent. Table 1 reported the respondents' demographic profile. 
Table 1 - Demographic Profile

\begin{tabular}{|c|c|c|}
\hline Profile & Frequency & Per cent \\
\hline \multicolumn{3}{|l|}{ Gender } \\
\hline Male & 172 & 44.6 \\
\hline Female & 214 & 55.4 \\
\hline \multicolumn{3}{|l|}{ Age } \\
\hline $20-30$ years old & 314 & 81.3 \\
\hline $31-40$ years old & 56 & 14.5 \\
\hline $41-50$ years old & 13 & 3.4 \\
\hline $51-60$ years old & 2 & .5 \\
\hline Above 60 years old & 1 & .3 \\
\hline \multicolumn{3}{|l|}{ Education level } \\
\hline High School & 13 & 3.4 \\
\hline Diploma & 55 & 14.2 \\
\hline Bachelor's degree & 251 & 65.0 \\
\hline Master & 65 & 16.8 \\
\hline Others & 2 & .5 \\
\hline \multicolumn{3}{|l|}{ Occupation } \\
\hline Unemployed & 14 & 3.6 \\
\hline Student & 33 & 8.5 \\
\hline Employed & 292 & 75.6 \\
\hline Self Employed & 47 & 12.2 \\
\hline \multicolumn{3}{|l|}{ Monthly Income } \\
\hline Less than RM 1000 & 45 & 11.7 \\
\hline RM 1001- RM 2000 & 55 & 14.2 \\
\hline RM 2001 to RM 3000 & 159 & 41.2 \\
\hline RM 3001 to RM 5000 & 77 & 19.9 \\
\hline More than RM 5000 & 50 & 13.0 \\
\hline
\end{tabular}

Note: $\mathrm{N}=386$.

Based on Table 1, most of the respondent is female $(n=214$; $55.4 \%)$ as compared to male respondent ( $n=172 ; 44.6 \%)$. Meanwhile, the result exhibits that most of the respondent's age is 20 to 30 years old ( $n=314 ; 81.3 \%$ ). Most of the young respondents are familiar with the mobile hotel booking service compared to the others. In terms of education level, most of the respondents are well educated with the majority of them hold bachelor's degrees $(n=251 ; 65 \%)$. Next, most of the respondents are employed ( $n=292 ; 75.6 \%)$. The result illustrates that most of the respondent's income falls within the category of RM2001 to RM3000 ( $n=159 ; 41.2 \%$ ).

\subsection{Descriptive Analysis}

The research items were descriptively analysed based on a fivepoint Likert-scale (1: strongly disagree, 2: disagree, 3: neutral, 4: agree, and 5: strongly agree). Table 2 reports the descriptive analysis findings.

Table 2 - Descriptive Analysis

\begin{tabular}{|c|c|c|c|}
\hline Code & Items & Mean & Std. Deviation \\
\hline PU1 & Using a mobile phone enables me to accomplish my hotel booking tasks faster. & 4.53 & .713 \\
\hline PU2 & Using a mobile phone makes it easier for me to perform my hotel booking. & 4.47 & .721 \\
\hline PU3 & Using a mobile phone to make a hotel booking is useful. & 4.53 & .664 \\
\hline PU4 & Using a mobile phone to make a hotel booking is advantageous. & 4.50 & .653 \\
\hline PEOU1 & Learning to make hotel bookings through mobile phone is easy for me. & 4.41 & .720 \\
\hline PEOU2 & It is easier to find information for hotel bookings through mobile phone. & 4.42 & .780 \\
\hline PEOU3 & Booking a hotel on the mobile phone is easy. & 4.03 & .936 \\
\hline PEOU4 & I believe that mobile apps are easy to use. & 4.41 & .751 \\
\hline PE1 & Using a mobile phone for hotel booking is enjoyable. & 4.03 & .801 \\
\hline PE2 & The actual process of using a mobile phone to make a hotel booking is pleasant. & 4.26 & .745 \\
\hline PE3 & It is exciting to use mobile phone for hotel booking tasks. & 3.96 & .908 \\
\hline PPV1 & I get a much reasonable price from mobile hotel booking. & 4.02 & .811 \\
\hline PPV2 & The discounts and promotions offered by mobile hotel booking platform provide value for me. & 4.01 & .808 \\
\hline PPV3 & Booking hotel rooms via mobile smartphones delivers good value & 4.06 & .721 \\
\hline $\mathrm{BI} 1$ & I would use a mobile phone to make hotel booking according to my needs. & 4.45 & .635 \\
\hline $\mathrm{BI} 2$ & Using a mobile phone in handling my hotel booking tasks is something I would do. & 4.38 & .678 \\
\hline $\mathrm{BI3}$ & I would see myself using the mobile phone to handle my future hotel booking. & 4.40 & .704 \\
\hline
\end{tabular}

Note: $\mathrm{N}=386$.

Based on the descriptive analysis as per Table 2, the mean score ranking is between 4.47 and 4.53 . Notably, most of the respondents agreed that using a mobile phone to perform hotel booking is advantageous and they perceived that hotel booking by mobile phone is easy to learn and easy to use. Next, most of them agreed that booking a hotel through the mobile phone is enjoyable and the process of hotel booking via mobile phone is pleasant. The majority of the respondents disagree that 
booking a hotel via mobile phone costs them higher. They would see themselves using a mobile phone as a medium to handle their hotel booking tasks.

\subsection{Measurement Model}

The measurement model evaluates indicator reliability, convergent validity, and discriminant validity. To assess the composite reliability (CR) of the research model, the item's factor loadings must exceed 0.70 (Bagozzi \& Yi, 1988; Hanafiah, 2020). Next, convergent validity is determined using the Average Variance Extracted (AVE) (Hair, Sarstedt, Hopkins, \&
Kuppelwieser, 2014). Bagozzi and Yi (1988) and Hair et al. (2014) suggested that the AVE value should be greater than 0.5 . The heterotrait-monotrait ratio of correlations (HTMT) is a new method for assessing discriminant validity in PLS-SEM. Henseler et al. (2009) proposed the superior performance of this method using a Monte Carlo simulation study and found that HTMT can achieve higher specificity and sensitivity rates compared to the cross-loadings criterion and Fornell-Lacker. Figure 1 reports the measurement model framework and Table 3 reports the measurement model assessment statistics.

Figure 1 - Measurement model

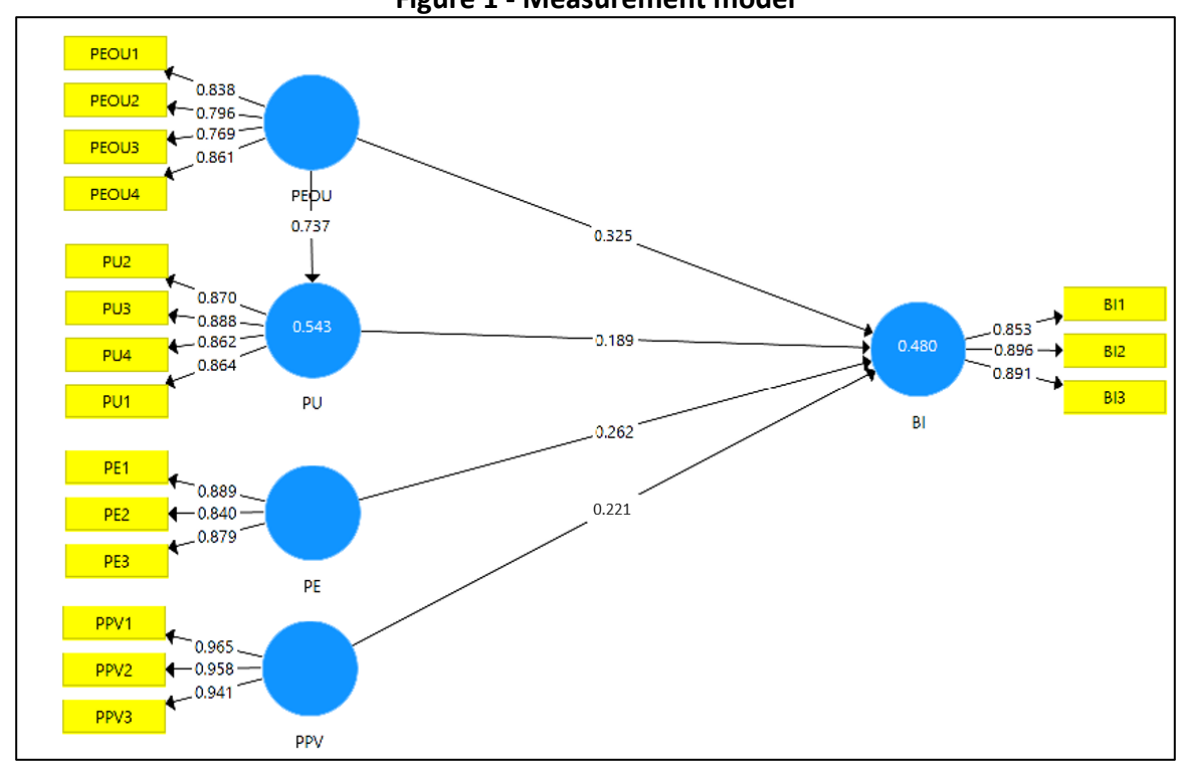

Table 3 - Measurement model statistics

\begin{tabular}{|c|c|c|c|c|c|}
\hline Constructs & Items & Outer Loadings & $\begin{array}{l}\text { Cronbach's } \\
\text { Alpha }\end{array}$ & $\begin{array}{l}\text { Composite } \\
\text { Reliability }\end{array}$ & $\begin{array}{l}\text { Average Variance } \\
\text { Extracted (AVE) }\end{array}$ \\
\hline \multirow{4}{*}{$\begin{array}{l}\text { Perceived Ease } \\
\text { of Use }\end{array}$} & PEOU1 & 0.838 & \multirow{4}{*}{0.834} & \multirow{4}{*}{0.889} & \multirow{4}{*}{0.667} \\
\hline & PEOU2 & 0.796 & & & \\
\hline & PEOU3 & 0.769 & & & \\
\hline & PEOU4 & 0.861 & & & \\
\hline \multirow{4}{*}{ Perceived Usefulness } & PU2 & 0.870 & \multirow{4}{*}{0.894} & \multirow{4}{*}{0.926} & \multirow{4}{*}{0.759} \\
\hline & PU3 & 0.888 & & & \\
\hline & PU4 & 0.862 & & & \\
\hline & PU1 & 0.864 & & & \\
\hline \multirow{3}{*}{ Perceived Enjoyment } & PE1 & 0.889 & \multirow[t]{3}{*}{0.838} & \multirow[t]{3}{*}{0.903} & \multirow{3}{*}{0.756} \\
\hline & PE2 & 0.840 & & & \\
\hline & PE3 & 0.879 & & & \\
\hline \multirow{3}{*}{ Price Value } & PPV1 & 0.965 & \multirow{3}{*}{0.852} & \multirow{3}{*}{0.869} & \multirow{3}{*}{0.812} \\
\hline & PPV2 & 0.958 & & & \\
\hline & PPV3 & 0.941 & & & \\
\hline \multirow{3}{*}{$\begin{array}{l}\text { Behavioural } \\
\text { Intention }\end{array}$} & BI1 & 0.853 & \multirow{3}{*}{0.855} & \multirow{3}{*}{0.912} & \multirow{3}{*}{0.775} \\
\hline & $\mathrm{B} 12$ & 0.896 & & & \\
\hline & $\mathrm{BI} 3$ & 0.891 & & & \\
\hline
\end{tabular}

Note: $\mathrm{N}=386$.

\section{Indicator Reliability}

The respective constructs were analysed in assessing the reliability of each indicator. Every loading is reviewed to verify whether all the individual items reliable, with the measurement items, are 0.70 and above. Based on Table 3, all items loaded significantly (loadings ranging from 0.769 to 0.965 ) onto their respective factors, verifying their indicator reliability (Fornell \& Larcker, 1981).

\section{Convergent Validity}

The measurement model used to collect consumer data had sufficient convergent validity based on the AVE value. Table 3 reports that the AVE values of all constructs are as follows: 
perceived ease of use (PEOU) (0.667), perceived usefulness (PU) (0.759), perceived enjoyment (PE) (0.756), perceived price value (PPV) (0.812), and behavioural intention (BI) (0.775). All of the AVE values were above the required minimum level of 0.50 , and exceeded the recommended cut-off parameters, exhibiting high levels of convergent validity and reliability.

\section{Discriminant Validity}

The heterotrait-monotrait ratio of correlations (HTMT) is a new method for assessing discriminant validity in PLS-SEM. Table 4 reports the HTMT statistics.

Table 4 - HTMT statistics

\begin{tabular}{|l|c|c|c|c|}
\hline & BI & PEOU & PE_ & PPV \\
\hline BI & 1 & & & \\
\hline PEOU & 0.749 & 1 & & \\
\hline PE & 0.686 & 0.782 & 1 & \\
\hline PPV & 0.100 & 0.091 & 0.098 & 1 \\
\hline PU & 0.679 & 0.843 & 0.704 & 0.094 \\
\hline
\end{tabular}

From the HTMT results, the values in Table 4 indicated no discriminant validity problems (HTMT $<0.85$ criterions). This result implied that the HTMT criterion did not detect the collinearity problems among the latent constructs (Henseler et al., 2009).

\section{Model Fit}

The goodness of fit (GoF) of the study model was assessed for both estimated and saturated models, according to Henseler et al. (2016), who indicated that the reporting of Standardised Root Mean Square Residual (SRMR) as an approximate measure of model fit.

Table 5 - Model Fit Summary

\begin{tabular}{|l|c|c|}
\hline & Saturated Model & Estimated Model \\
\hline SRMR & 0.058 & 0.064 \\
\hline d_ULS & 0.517 & 0.630 \\
\hline d_G & 0.274 & 0.280 \\
\hline Chi-Square & 634.732 & 634.524 \\
\hline NFI & 0.866 & 0.866 \\
\hline
\end{tabular}

Based on the table above, the SRMR value for this study framework is 0.064 , and the results indicated that this model fulfils the criterion of SRMR $<0.08$ (Henseler et al., 2016). Based on the finalised measurement model, behavioural intention (BI) can be explained by four reflective constructs that are perceived ease of use (PEOU), perceived usefulness (PU), perceived enjoyment (PE), and price value (PV).

\subsection{Structural Modelling}

Having established a reliable and valid measurement model, the next step of analysis is structural modelling. The criteria used in assessing the structural model involved analysing the coefficient of determination $\left(R^{2}\right)$, estimation of path coefficient $(\beta)$, effect size $\left(f^{2}\right)$, and prediction relevance $\left(q^{2}\right)$ (Chin, 2010; Hair et al., 2014; Hanafiah, 2020). First, the significance level of the path relationship was examined through the regression coefficient $(\beta)$ value obtained using the SmartPLS 3.1 Bootstrapping process. Table 6 lists the path coefficients, observed t-statistics, and significance levels for all hypothesised path. Using the path assessment results, the proposed hypotheses were either accepted or rejected, as is elaborated in the following section.

Table 6 - Path analysis

\begin{tabular}{|l|c|c|c|c|c|}
\hline & Beta Coefficient & Standard Deviation & T Statistics & P Values & Hypotheses testing \\
\hline PEOU $>$ PU & $0.739^{* * *}$ & 0.034 & 21.895 & 0.000 & Accepted \\
\hline $\mathrm{PU}>\mathrm{BI}$ & $0.190^{* * *}$ & 0.078 & 2.410 & 0.016 & Accepted \\
\hline $\mathrm{PEOU}>\mathrm{BI}$ & $0.318^{* * *}$ & 0.069 & 4.705 & 0.000 & Accepted \\
\hline $\mathrm{PE}>\mathrm{BI}$ & $0.267^{* * *}$ & 0.052 & 4.997 & 0.000 & Accepted \\
\hline $\mathrm{PPV}>\mathrm{BI}$ & $0.072^{* *}$ & 0.035 & 1.993 & 0.047 & Accepted \\
\hline
\end{tabular}

The first hypothesis proposed that perceived ease of use (PEOU) positively influences perceived usefulness (PU). Based on the path analysis, the beta coefficient value $(\beta=.739 * * *)$ confirms that perceived ease of use (PEOU) affects perceived usefulness (PU). Thus, the first hypothesis: perceived ease of use (PEOU) positively influences perceived usefulness (PU) is supported. The second hypothesis tested the relationship between perceived usefulness (PU) and behavioural intention (BI). From the path analysis, the beta coefficient value $\left(\beta=.190^{* * *}\right)$ result confirms that the perceived usefulness (PU) influences behavioural intention (BI). Thus, the second hypothesis: perceived usefulness (PU) positively influences behavioural intention (BI) is supported. The third hypothesis tested the relationship between perceived ease of use (PEOU) and behavioural intention (BI). Based on the path analysis, the beta coefficient value $\left(\beta=.318^{* * *}\right)$ result shows that the perceived ease of use (PEOU) influences behavioural intention (BI). Thus, the third hypothesis: perceived ease of use (PEOU) 
positively influences the behavioural intention (BI) is accepted. The fourth hypothesis tested the relationship between perceived enjoyment $(\mathrm{PE})$ and behavioural intention (BI). The beta coefficient value $\left(\beta=.267^{* * *}\right)$ result shows that perceived enjoyment $(\mathrm{PE})$ influences behavioural intention (BI). Thus, the hypothesis: perceived enjoyment (PE) positively influences behavioural intention (BI) is accepted. The fifth hypothesis tested the relationship between perceived price value (PPV) and behavioural intention (BI). Based on the path analysis, the beta coefficient value $\left(\beta=.072^{* *}\right)$ result indicates that perceived price value (PPV) positively influenced behavioural intention (BI). Thus, the fifth hypothesis is accepted.

Next, the $R^{2}$ value represents the amount of variance in the dependent variables that are explainable by the independent variables (Hair et al., 2014). This study confirms that perceived ease of use (PEOU) can explain $54.3 \%$ of the perceived usefulness (PU) variances based on the path analysis. Next, this study also confirms that perceived ease of use (PEOU), perceived usefulness (PU), perceived enjoyment (PE), and price value $(\mathrm{PV})$ can explain $48 \%$ of the variances in behavioural intention (BI). On the other hand, the effect size function $\left(f^{2}\right)$, which is similar to the traditional partial F-test (Sarstedt, Ringle, \& Hair, 2017) The effect size explains increases in $R^{2}$ relative to the proportion of variance of the dependent variable that remains unexplained (Chin, 2010). This study confirms that perceived ease of use (PEOU) has a substantial effect on perceived usefulness (PU) $\left(f^{2}=0.188\right)$. Meanwhile, this study also confirms that perceived ease of use (PEOU) $\left(f^{2}=0.078\right)$, perceived usefulness (PU) $\left(f^{2}=0.029\right)$ and perceived enjoyment (PE) $\left(f^{2}=0.067\right)$ have a modest effect on behavioural intention (BI). Lastly, this study found perceived price value (PPV) ( $f$ ${ }^{2}=0.009$ ) has a weak effect on behavioural intention (BI).

\section{Discussion and Conclusion}

\subsection{Discussion}

The current study aims to incorporate perceived enjoyment and perceived value in the modified Technology Acceptance Model (m-TAM) and tested it as a unified model. In this regard, the impacts of perceived usefulness, perceived ease of use, perceived enjoyment, and perceived price value (PPV) on mobile hotel booking customers' behavioural intentions were examined. This study confirms that the modified TAM ( $m$-TAM) framework can explain consumer behaviour towards technology adoption and usage based on hypothesis testing. This study confirms that perceived ease of use significantly influences perceived usefulness of mobile hotel booking based on the research framework structural modelling. Next, this study also confirms that behavioural intention (BI) of mobile hotel booking can be predicted by the perceived ease of use, perceived usefulness, perceived enjoyment, and perceived price value. In terms of the relationship between perceived ease of use and perceived usefulness, this study result are in line with other researchers' findings: perceived ease of use certainly positively affects perceived usefulness. Notably, this is consistent with the proposition from the original TAM model (Venkatesh et al. 2003; Huang \& Chuang, 2007; Yang et al., 2013). Özbek et al. (2015), in their research, explained that people would consider using mobile hotel booking if it is useful to them and if the effort to use technology is accessible. This study also illustrated that perceived usefulness is the predictor of intention to use mobile hotel booking. The results are in line with previous research findings. Weng, Zailani, Iranmanesh, and Hyun (2017) found that user continuation intention to use mobile hotel booking has been heavily influenced by perceived usefulness. Meanwhile, Lee, Haque, and Maulan (2018) regard perceived usefulness as a significant factor in online buying intention and consistent with several past studies that focused on the online environment. They further elaborated that this is because people perceived online buying as useful, which boosts their intention to buy online.

Next, like other researchers' findings, this study found that perceived ease of use influences behavioural intention (Yang et al., 2013; Morosan, 2014; Özbek et al., 2015; Suki \& Suki, 2017). They claimed that mobile devices introduce both convenience and easiness to contemporary travellers. As per Abdullah et al. (2017), customers will adopt technology when there is understandable interaction of the user with a particular technology, and they feel comfortable using the technology to do what they want. This study explains the positive influence between perceived ease of use and behavioural intention. When customers ought that mobile hotel booking is easy to use, they are willing to learn more, which can influence them to use the technology. It follows Liu and Tai (2016) that customers who can use the technology service easily will lead them to use it again and incorporate the function of new services to their daily life activities. Meanwhile, Davis et al. (1992), in their research, has added perceived enjoyment to the original TAM and found that it has a significant effect on behavioural intention to adopt the technology. Dwivedi, Tamilmani, Williams, and Lal (2014) claimed that perceived enjoyment is a significant predictor in determining customer behavioural intention towards the adoption of mobile-based technology. They further elaborate that users intend to continue using this particular technology if they find it enjoyable and pleasant. Suki and Suki (2017) also expressed the same thought with further explanation that people are driven to perform the more enjoyable activity as compared to the similar activity that is not enjoyable, and if the user experience enjoyment through new technology adoption, the result will lead to the positive influence to the user itself. As for this research, the result is in line with past researchers with the proposed hypothesis is accepted, which is perceived enjoyment positively influence customer behavioural intention to adopt mobile hotel booking. This positive outcome explains that making hotel booking through mobile phones is enjoyable, pleasant, and useful, making them more ready to use mobile hotel bookings.

As presented in our findings, the perceived price value was found to positively and significantly influence behavioural 
intention to adopt mobile hotel booking. This study reflects that price value does influence consumers' intention to use mobile hotel bookings. Yang et al. (2013) stated that customers intend to use mobile travel booking if they get discounts and the service provided is convenient for them. Furthermore, Wei et al. (2009) claimed that customers would adopt mobile commerce if they received a sense of price value. Chong et al. (2011) and Chong (2013) further explained that if customers have to adopt expensive technology, they may not be willing to adopt. Thus, it is safe to assume that consumers are willing to adopt technology if it can benefit them more in return. Notably, mobile hotel booking can provide an easier way to book a room at the same time provide more information about the hotel in terms of food and beverages, details of the hotel itself compared to the traditional method of booking that requires them to walk in or call if they want to book or have an inquiry regarding the hotel itself.

\subsection{Conclusion}

This study contributes to the user m-commerce adoption literature by incorporating perceived enjoyment and perceived value in the modified Technology Acceptance Model (m-TAM) and tested it as a unified model. Notably, this study confirms that the modified TAM (m-TAM) framework can explain consumer behaviour. This study specifically found that perceived usefulness and perceived ease of use are the key determinants of user adoption of mobile hotel booking. This study also confirms that TAM can be extended and employed to predict and explain the acceptance of the new technologies in service industries. The findings provided a reference for future TAM and mobile booking related studies. Future researchers should extend TAM with other attitudinal attributes (e.g., technology readiness) and employed Covariance based - Structural Equation Modelling (CB-SEM) to confirm the m-TAM framework. The author also hopes this research can provide insight into future researchers on Malaysia's mobile hotel booking situation. In line with Malaysia's government effort to support information technology (IT) adoption, Malaysian hotel owners and managers should adopt mobile hotel booking as part of their marketing strategy to attract customers. This action would enhance Malaysia image and reputation as a modern tourism destination embracing the latest technology.

This study provides a much extensive explanation of the consumer intention to use mobile technology to make a hotel booking. Though this is not the first paper to produce this kind of research, this study offers new insight, especially by integrating perceived enjoyment and perceived price value in the m-TAM model. In terms of practical perspectives, the findings from this research can be used by the business organisation involved in the hospitality industry, mainly hotel as they primarily rely on online booking that includes mobile booking. As investment in technology is expensive, designing a convenient and easy to use environment of mobile hotel booking is essential for the hotel brands. With this newfound result, it can bring awareness of how significant the potential is to use a mobile platform to make a hotel booking. Thus, the hotel industry players need to realise that booking hotel through mobile is the latest trend and should make full use of this technology immediately.

Meanwhile, there are several limitations that researchers found. The first limitation of this research is the unequal age distribution as the majority of age distribution fall in the group of younger age generation. If the response is evenly distributed, the result might differ as different generations have a different perception, which can produce a more generalised result. Another limitation is that there is no exact number of Malaysian populations that use the mobile phone, which leads to an unknown number of populations. Thus, future research needs to have an exact population number to determine the appropriate sample size. Finally, this research is a crosssectional study, and it can be assumed that the respondent's perception and behavioural intention might eventually change over time. It can make the study irrelevant in the future due to the research only focus on a single moment and did not consider what happens before or after the research has been conducted. The outcome could be varying if the researchers apply a longitudinal study.

\section{Acknowledgment}

The researchers would like to acknowledge the Ministry of Education, Malaysia, for funding this study through the Fundamental Research Grant Scheme (FRGS): 600-IRMI/FRGS 5/3 (468/2019).

\section{References}

Abdullah, D., Jayaraman, K., \& Kamal, S. B. M. (2016). A Conceptual Model of Interactive Hotel Website: The Role of Perceived Website Interactivity and Customer Perceived Value Toward Website Revisit Intention. Procedia Economics and Finance, 37, 170-175. http://doi.org/10.1016/S2212-5671(16)30109-5

Abdullah, D., Jayaraman, K., Shariff, D. N., Bahari, K. A., \& Nor, N. M. (2017). The effects of perceived interactivity, perceived ease of use and perceived usefulness on online hotel booking intention: A conceptual framework. International Academic Research Journal of Social Science, 3(1), 16-23.

Abdullah, D., Radzi, S. M., Jamaluddin, M. R., \& Patah, M. O. R. A. (2010). Hotel web site evaluation and business travelers' preferences. ICETC 2010 - 2010 2nd International Conference on Education Technology and Computer, 3, 485-488. https://doi.org/10.1109/ICETC.2010.5529493.

Agag, G., \& El-Masry, A. A. (2016). Understanding the determinants of hotel booking intentions and moderating role of habit. International Journal of Hospitality Management, 54, 52-67. https://doi.org/10.1016/j.ijhm.2016.01.007.

Ajmal, F. (2017). Factors influencing electronic commerce adoption in Malaysian Small and Medium Sized Enterprises (SMEs). (Doctorate Thesis), University of Malaya Kuala Lumpur.

Ajzen, I (1991). The theory of planned behavior. Organisation Behavior and Human Decision Processes, 50(2), 79-211. https://doi.org/10.1016/0749-5978(91)90020-T.

Alalwan, A. A., Baabdullah, A. M., Rana, N. P., Tamilmani, K., \& Dwivedi, Y. K. (2018). Examining adoption of mobile internet in Saudi Arabia: Extending TAM with perceived enjoyment, innovativeness and trust. Technology in Society, 55, 100-110.

https://doi.org/10.1016/j.techsoc.2018.06.007. 
Albers, M. J. (2017). Introduction to Quantitative Data Analysis in the Behavioral and Social Sciences. New York: John Wiley \& Sons. https://doi.org/10.1002/9781119290384.

Amaro, S., \& Duarte, P. (2015). An Integrative Model of Consumers Intentions to Purchase Travel Online. Tourism Management, 46, 64-79. https://doi.org/10.1016/j.tourman.2014.06.006.

Bagozzi, R. P., \& Yi, Y. (1988). On the evaluation of structural equation models. Journal of the Academy of Marketing Science, 16(1), 74-94. https://doi.org/10.1007/BF02723327.

Bhatiasevi, V., \& Yoopetch, C. (2015). The Determinants of Intention to Use Electronic Booking among Young Users in Thailand. Journal of Hospitality and Tourism Management, 23, 1-11. https://doi.org/10.1016/j.jhtm.2014.12.004.

Chan, L. L., \& Idris, N. (2017). Validity and reliability of the instrument using exploratory factor analysis and Cronbach's alpha. International Journal of Academic Research in Business and Social Sciences, 7(10), 400-410. https://doi.org/10.6007/IJARBSS/v7-i10/3387.

Chen, J. V., Yen, D. C., \& Chen, K. (2009). The Acceptance and Diffusion of the Innovative Smart Phone Use: A Case Study of a Delivery Service Company in Logistics. Information and Management, 46(4), 241-248. https://doi.org/10.1016/j.im.2009.03.001.

Chin, W. W. (2010). How to write up and report PLS analyses. In Handbook of partial least squares (pp. 655-690). Springer, Berlin, Heidelberg. https://doi.org/10.1007/978-3-540-32827-8_29.

Chin, L. P., \& Ahmad, Z. A. (2015). Perceived Enjoyment and Malaysian Consumers' Intention to Use a Single Platform E-Payment. In SHS Web of Conferences (Vol. 18). EDP Sciences.

https://doi.org/10.1051/shsconf/20151801009.

Chong, A. Y. (2013). A Two-Staged SEM-Neural Network Approach for Understanding and Predicting the Determinants of M-Commerce Adoption. Expert Systems with Applications, 40(4), 1240-1247. doi:10.1016/j.eswa.2012.08.067

Chong, A. Y. L., (2013) "A Two-Staged SEM-Neural Network Approach for Understanding and Predicting the Determinants of M-Commerce Adoption", Expert Systems with Applications, 40(4), 1240-1247. https://doi.org/10.1016/j.eswa.2012.08.067.

Davis, F. D., Bagozzi, R. P., \& Warshaw, P. R. (1992). Extrinsic and Intrinsic Motivation to Use Computers in the Workplace. Journal of Applied Social Psychology, 22(14), 1111-1132. https://doi.org/10.1111/j.1559-1816.1992.tb00945.x.

Davis, F.D., (1989), Perceived Usefulness, Perceived Ease of Use, and User Acceptance of Information Technology. MIS Quarterly. 13(3), 319340. https://doi.org/10.2307/249008.

Davis, Fred D., Bagozzi, R. \& Warshaw, P. (1989). User Acceptance of Computer Technology: A Comparison of Two theoretical models," Management Science, 35, 982-1003. https://doi.org/10.1287/mnsc.35.8.982.

Department of Statistics Malaysia. (2019). Federal Territory of Kuala Lumpur Population at a Glance. Retrieved November 30, 2019, from https://www.dosm.gov.my

Dias, S. F., \& Afonso, V. A. (2020). Innovative Business Models in Tourism and Hospitality: Going Mobile? In Strategic Business Models to Support Demand, Supply, and Destination Management in the Tourism and Hospitality Industry (pp. 164-184). IGI Global. https://doi.org/10.4018/978-1-5225-9936-4.ch009.

Dwivedi, Y. K., Tamilmani, K., Williams, M. D., \& Lal, B. (2014). Adoption of M-commerce: Examining factors affecting intention and behaviour of Indian consumers. International Journal of Indian Culture and Business Management, 8(3), 345. https://doi.org/10.1504/IJICBM.2014.060365.

Fishbein, M. \& Ajzen, I. (1975). Belief, Attitude, Intention and Behavior: An Introduction to Theory and Research. Reading, MA: Addison-Wesley. Fong, L. H. N., Lam, L. W., \& Law, R. (2017). How locus of control shapes intention to reuse mobile apps for making hotel reservations: Evidence from Chinese consumers. Tourism Management, 61, 331-342. https://doi.org/10.1016/j.tourman.2017.03.002.
Fornell, C., \& Larcker, D. F. (1981). Structural equation models with unobservable variables and measurement error: Algebra and statistics. Journal of Marketing Research, 382-388. https://doi.org/10.1177/002224378101800313.

Gao, S., Krogstie, J., \& Siau, K. (2014). Adoption of Mobile Information Services: An Empirical Study. Mobile Information Systems, 10(2), 147 171. https://doi.org/10.1155/2014/146435.

Goi, C. L. (2016). M-Commerce: Perception of Consumers in Malaysia. Journal of Internet Banking and Commerce, 21(S5), 1-13.

Gurtner, S., Reinhardt, R., \& Soyez, K. (2014). Designing mobile business applications for different age groups. Technological Forecasting and Social Change, 88, 177-188.

https://doi.org/10.1016/j.techfore.2014.06.020.

Hahn, S., Yoon, J.-H., \& Kim, J.-M. (2014). Extending the Technology Acceptance Model to Examine the Intention to Use Tourism Applications on Smartphone. Hotel Management Research Volume 23(3), 19-40.

Hanafiah, M. H. (2020). Formative Vs. Reflective Measurement Model: Guidelines for Structural Equation Modeling Research. International Journal of Analysis and Applications, 18(5), 876-889.

Hair, J. F., Money, A. H., Samouel, P., \& Page, M. (2007). Research Methods for Business. England: John Wiley \& Sons Ltd.

Hair Jr, J. F., Sarstedt, M., Hopkins, L., \& Kuppelwieser, V. G. (2014). Partial least squares structural equation modeling (PLS-SEM). European Business Review, 26(2), 106-121. https://doi.org/10.1108/EBR-102013-0128.

Hashim, N. A., Mohd Nor, S., \& Janor, H. (2016). Riding the waves of social commerce: An empirical study of Malaysian entrepreneurs. Geografia: Malaysian Journal of Society and Space, 12(2), 83-94.

Henseler, J., Ringle, C. M., \& Sinkovics, R. R. (2009). The use of partial least squares path modeling in international marketing. In New Challenges to International Marketing (pp. 277-319). Emerald Group Publishing Limited. https://doi.org/10.1108/S14747979(2009)0000020014.

Henseler, J., Hubona, G., \& Ray, P. A. (2016). Using PLS path modeling in new technology research: updated guidelines. Industrial Management \& Data Systems, 116(1), 2-20. https://doi.org/10.1108/IMDS-09-2015-0382.

Hill, R. (1998). What sample size is "enough" in internet survey research? Interpersonal Computing and Technology: An Electronic Journal for the 21st Century, 6(3-4).

Huang, J., Lin, Y., \& Chuang, S. (2007). Elucidating user behavior of mobile learning. The Electronic Library, 25(5), 585-598. https://doi.org/10.1108/02640470710829569.

Hussain, A., Mkpojiogu, E. O., \& Yusof, M. M. (2016). Perceived usefulness, perceived ease of use, and perceived enjoyment as drivers for the user acceptance of interactive mobile maps. AIPC, 1761(1), 2051. https://doi.org/10.1063/1.4960891.

Huynh, Q. L., \& Thi, T. L. (2014). The Mediating Role of the Perceived Usefulness in the Acceptance of E-learning. International Journal of Humanities and Social Science Invention, 3(2), 37-42.

Jeon. J., (2015). The Strengths and Limitations of the Statistical Modeling of Complex Social Phenomenon: Focusing on SEM, Path Analysis, or Multiple Regression Models. International Journal of Social, Behavioral, Economic, Business and Industrial Engineering, 9(5), 16341642.

Jiang, G., Peng, L., \& Liu, R. (2015). Mobile Game Adoption in China: The Role of TAM and Perceived Entertainment, Cost, Similarity and Brand Trust. International Journal of Hybrid Information Technology, 8(4), 213-232. https://doi.org/10.14257/ijhit.2015.8.4.24.

Kaushik, A. K., Agrawal, A. K., \& Rahman, Z. (2015). Tourist behaviour towards self-service hotel technology adoption: Trust and subjective norm as key antecedents. Tourism Management Perspectives, 16, 278 289. https://doi.org/10.1016/j.tmp.2015.09.002 
Khalid, H., Shihab, E., Nagappan, M., \& Hassan, A. E. (2015). What Do Mobile App Users Complain About? IEEE Software, 32(3), 70-77. https://doi.org/10.1109/MS.2014.50.

Khalid, N. (2014). The Role of Perceived Usefulness and Perceived Enjoyment in Assessing Students' Intention to Use LMS Using 3-Tum. Proceeding of the Global Summit on Education (pp. 425-432). Kuala Lumpur: WorldConferences.net.

Kim, C., Mirusmonov, M., \& Lee, I. (2010). An empirical examination of factors influencing the intention to use mobile payment. Computers in Human Behaviour, 26(3), 310-322. https://doi.org/10.1016/j.chb.2009.10.013.

Kim, D., Park, J., \& Morrison, A. M. (2008). A model of traveller acceptance of mobile technology. International Journal of Tourism Research, 10(5), 393-407. https://doi.org/10.1002/jtr.669.

Kim, H.W., H.C. Chan \& S. Gupta (2007). "Value-based Adoption of Mobile Internet: An Empirical Investigation," Decision Support Systems (43), 111 -26. https://doi.org/10.1016/j.dss.2005.05.009.

Kim, J. (2016). An extended technology acceptance model in behavioral intention toward hotel tablet apps with moderating effects of gender and age. International Journal of Contemporary Hospitality Management, 28(8), 1535-1553. https://doi.org/10.1108/IJCHM-062015-0289.

Kim, J., Christodoulidou, N. \& Brewer, P. (2011), "Impact of individual difference and consumers' readiness on likelihood of using self-service technologies at hospitality settings". Journal of Hospitality and Tourism Research, 35(3), 85-114. https://doi.org/10.1177/1096348011407311.

Kim, M. \& Qu, H. (2014), Travelers' behavioral intention toward hotel self-service kiosks usage. International Journal of Contemporary Hospitality Management, 26(2), 225-245. https://doi.org/10.1108/IJCHM-09-2012-0165.

Kim, S. H. (2008). Moderating effects of Job Relevance and Experience on mobile wireless technology acceptance: Adoption of a smartphone by individuals. Information \& Management, 45(6), 387-393. https://doi.org/10.1016/j.im.2008.05.002.

Kitcharoen, K. (2019). The effect of e-word of mouth (E-WOM) on various factors influencing customers' hotel booking intention. $A B A C$ ODI Journal Vision. Action. Outcome, 6(1), 62.

Ko, Y. K. \& Kim, K. H. (2011). Analysis on the factors that affect the user's intention of reusing mobile app-based tourism contents. Journal of the Korea Contents Association, 11(12), 844-855. https://doi.org/10.5392/JKCA.2011.11.12.844.

Krejcie, R. V, \& Morgan, D. W. (1970). Determining Sample Size for Research Activities. Educational and Psychological Measurement, 30, 607-610. https://doi.org/10.1177/001316447003000308

Kucukusta, D., Law, R., Sahli, A. B., \& Legoherel, P. (2015). Re-examining perceived usefulness and ease of use in online booking: The case of Hong Kong online users. International Journal of Contemporary Hospitality Management, 2(27), 185-198. https://doi.org/10.1108/IJCHM-09-2013-0413.

Kumar, M., Salim Abdul Talib, Ramayah, T. (2013). Business Research Methods (1st ed.). India: Oxford Fajar Sdn. Bhd.

Kwon, J. M., Bae, J., \& Blum, S. C. (2013). Mobile applications in the hospitality industry. Journal of Hospitality and Tourism Technology, 4(1), 81-92. https://doi.org/10.1108/17579881311302365.

Law, R., Leung, R., Lo, A., Leung, D., \& Fong, L. H. N. (2015). Distribution channel in hospitality and tourism: Revisiting disintermediation from the perspectives of hotels and travel agencies. International Journal of Contemporary Hospitality Management, 27(3), 431-452. https://doi.org/10.1108/IJCHM-11-2013-0498.

Lee, T. H. \& Park, L. W. (2013). Study on utilisation and circulation toward smartphone application of travel agencies based on the extended technology acceptance model. Journal of Tourism Sciences, 37(6), 287-308.

Leong, L. Y., Hew, T. S., Ooi, K. B., \& Lin, B. (2019). Do electronic wordof-mouth and elaboration likelihood model influence hotel booking?. Journal of Computer Information Systems, 59(2), 146-160. https://doi.org/10.1080/08874417.2017.1320953.

Leong, L. Y., Ooi, K. B., Chong, A. Y. L., \& Lin, B. (2011). Influence of individual characteristics, perceived usefulness and perceived ease of use on mobile entertainment adoption in Malaysia - an SEM approach. International Journal of Mobile Communications, 9(44), 359-382. https://doi.org/10.1504/IJMC.2011.041141.

Leung, D., Fong, L. H. N., \& Law, R. (2013). Assessing the visibility of hotels on smartphones: A case study of hotels in Hong Kong. In Information and communication technologies in tourism 2014 (pp. 841-854). Springer, Cham. https://doi.org/10.1007/978-3-319-039732_61.

Leung, D., Lee, H.A., Fong, L Lee, K., Haque, A., \& Maulan, S. (2018). Understanding the Effect of Consumer Perceptions on Buying Intention for Air Tickets Online in Malaysia. International Journal of Academic Research in Business and Social Sciences, 8(2). https://doi.org/10.6007/IJARBSS/v8-i2/3883.

Liang, S., Schuckert, M., Law, R., \& Masiero, L. (2017). The relevance of mobile tourism and information technology: an analysis of recent trends and future research directions. Journal of Travel \& Tourism Marketing, 34(6), 732-748.

https://doi.org/10.1080/10548408.2016.1218403.

Linton, H., \& Kwortnik, R. J. (2015). The Mobile Revolution Is Here: Are You Ready? Cornell Hospitality Report, 15(6), 1-18.

Liu X, Wei K. K. (2003). An empirical study of product differences in consumers' e-commerce adoption behavior. Electronic Commerce Research and Applications, 2, 229-239. https://doi.org/10.1016/S15674223(03)00027-9.

Liu, C., \& Cheng, T. (2015). Exploring critical factors influencing physicians' acceptance of mobile electronic medical records based on the dual-factor model: A validation in Taiwan. BMC Medical Informatics and Decision Making, 15(1). https://doi.org/10.1186/s12911-0140125-3.

Liu, G., \& Tai, P. T. (2016). A Study of Factors Affecting the Intention to Use Mobile Payment Services in Vietnam. Economics World, 4(6). https://doi.org/10.17265/2328-7144/2016.06.001.

Moorthy, K., Ling, C. S., Fatt, Y. W., Yee, C. M., Yin, E. C., Yee, K. S., \& Wei, L. K. (2017). Barriers of Mobile Commerce Adoption Intention: Perceptions of Generation X in Malaysia. Journal of Theoretical and Applied Electronic Commerce Research, 12(2), 37-53. https://doi.org/10.4067/S0718-18762017000200004.

Morosan, C. (2014), "Toward an integrated model of adoption of mobile phones for purchasing ancillary services in air travel". International Journal of Contemporary Hospitality Management, 27 (2), 246-271. https://doi.org/10.1108/IJCHM-11-2012-0221.

Muñoz-Leiva, F., Climent-Climent, S., \& Liébana-Cabanillas, F. (2017) Determinants of intention to use the mobile banking apps: An extension of the classic TAM model. Spanish Journal of Marketing - ESIC, 21(1), 25 38. https://doi.org/10.1016/j.sjme.2016.12.001.

Murphy, H. C., Chen, M. M., \& Cossutta, M. (2016). An investigation of multiple devices and information sources used in the hotel booking process. Tourism Management, 52, 44-51.

https://doi.org/10.1016/j.tourman.2015.06.004.

Nikou, S. A., \& Economides, A. A. (2015). The effects of Perceived Mobility and Satisfaction on the adoption of Mobile-based Assessment. Education, 7(8), 9-21.

https://doi.org/10.1109/IMCTL.2015.7359579.

Özbek, V., Günalan, M., Koç, F., Sahin, N. K., \& Kas, E. (2015). The effects of perceived risk and cost on technology acceptance: A study on tourists' use of online booking. Journal of Social Sciences, 13(2), 23-34. https://doi.org/10.18026/cbusos.49782.

Ozturk, A. B., Bilgihan, A., Nusair, K., \& Okumus, F. (2015). Mobile Hotel Booking Technology in the Hotel Industry. The 3rd International Academic Conference on Social Science (pp. 295-300). Istanbul: The International Institute for Academic Development. 
Ozturk, A. B., Nusair, K., Okumus, F., \& Singh, D. (2017). Understanding mobile hotel booking loyalty: an integration of privacy calculus theory and trust-risk framework. Information Systems Frontiers, 19(4), 753767. https://doi.org/10.1007/s10796-017-9736-4.

Park, E., \& Kim, K. J. (2013). User acceptance of long-term evolution (LTE) services. Program: Electronic Library and Information Systems, 47(2), 188-205. https://doi.org/10.1108/00330331311313762.

Park, E., \& Kim, K. J. (2013). User Acceptance of Long-Term Evolution (LTE) Services. Program, 47(2), 188-205. https://doi.org/10.1108/00330331311313762.

Park, S., \& Huang, Y. (2017). Motivators and inhibitors in booking a hotel via smartphones. International Journal of Contemporary Hospitality Management, 29(1), 161-178. https://doi.org/10.1108/IJCHM-032015-0103

Rodzi, F. N., Mohd Nasir, E. A., Azmi, A. L., Abdullah, D., Azmi, A., \& Mohd Kamal, S. B. (2016). The Role of Compatibility, Information Quality and e-Service Quality in Predicting Mobile Hotel Booking Adoption: A Conceptual Framework. International Academic Research Journal of Business and Technology, 2(2), 123-128.

Saw, S. L., Goh, Y. N., \& Mohd Isa, S. (2015). Exploring consumers' intention toward online hotel reservations: Insights from Malaysia. Problems and Perspectives in Management, 13(2), 78-92.

Sekaran, U., \& Bougie, R. (2009). Research Methods for Business: A SkillBuilding Approach (5th ed.). United Kingdom: John Wiley \& Sons Ltd.

Shatskikh, A. (2013). Consumer acceptance of Mobile Payments in Restaurants (Graduate Theses and Dissertations). University of South Florida.

Shaw, N. (2016). Adoption of Smartphone Apps by Hotel Guests: The Roles of Trust and Word of Mouth. $\mathrm{HCl}$ in Business, Government, and Organisations: Information Systems Lecture Notes in Computer Science, 457-468. https://doi.org/10.1007/978-3-319-39399-5_43.

Smith, S. (2013). Determining sample size: How to ensure you get the correct sample size. E-Book (c) Qualtrics Online Sample.

Suki, N. M., \& Suki, N. M. (2011). Exploring the Relationship Between Perceived Usefulness, Perceived Ease of Use, Perceived Enjoyment, Attitude and Subscriber's Intention Towards Using Mobile 3G Services. Journal of Information Technology Management, 22(1), 1-7.

Suki, N. M., \& Suki, N. M. (2017). Flight ticket booking app on mobile devices: Examining the determinants of individual intention to use. Journal of Air Transport Management, 62, 146-154. https://doi.org/10.1016/j.jairtraman.2017.04.003.

Sarstedt, M., Ringle, C. M., \& Hair, J. F. (2017). Partial least squares structural equation modeling. In Handbook of Market Research (pp. 140). Springer International Publishing. https://doi.org/10.1007/978-3319-05542-8_15-1.

Tao, M., Nawaz, M. Z., Nawaz, S., Butt, A. H., \& Ahmad, H. (2018). Users' acceptance of innovative mobile hotel booking trends: UK vs. PRC. Information Technology \& Tourism, 20(1-4), 9-36.

Ting, Y. S., \& Hsu, Y. L. (2013). Global Hotel Reservation Trends in Terms of Mobile App Application via Smartphone. Journal of Travel \& Tourism Marketing, 30(2), 28-34.

Venkatesh, V., Morris, M. G., Davis, G. B., \& Davis, F. D. (2003). User Acceptance of Information Technology: Toward a Unified View. MIS Quarterly, 27(3), 425-478. https://doi.org/10.2307/30036540.

Venkatesh, V., Thong, J. Y., \&Xu, X. (2012). Consumer acceptance and use of information technology: Extending the unified theory of acceptance and use of technology. MIS Quarterly, 36(1), 157-178. https://doi.org/10.2307/41410412.

Vijayasarathy, L. R., \& Jones, J. M. (2000). Print and Internet catalog shopping: assessing attitudes and intentions. Internet Research: Electronic Networking Applications and Policy, 10(3), 191-202. https://doi.org/10.1108/10662240010331948.

Wang, D., Xiang, Z., Law, R., \& Ki, T. P. (2016). Assessing hotel-related smartphone apps using online reviews. Journal of Hospitality Marketing \& Management, 25(3), 291-313.

https://doi.org/10.1080/19368623.2015.1012282.
Wang, H.-Y., \& Wang, S.-H. (2010). Predicting Mobile Hotel Reservation Adoption: Insight from a Perceived Value Standpoint. International Journal of Hospitality Management 29, 598-608. https://doi.org/10.1016/j.ijhm.2009.11.001.

Wei, T. T., Marthandan, G., Chong, A. L., Ooi, K. B., \& Arumugam, S. (2009). What drives Malaysian m-commerce adoption? An empirical analysis. Industrial Management \& Data Systems, 109(3),370-388. https://doi.org/10.1108/02635570910939399.

Weng, G. S., Zailani, S., Iranmanesh, M., \& Hyun, S. S. (2017). Mobile taxi booking application service's continuance usage intention by users. Transportation Research Part D: Transport and Environment, 57, 207 216. https://doi.org/10.1016/j.trd.2017.07.023.

Wozniak, T., Schaffner, D., Stanoevska-Slabeva, K., \& Lenz-Kesekamp, V. (2017). Psychological Antecedents of Smartphone Users' Behaviour Along the Mobile Customer Journey. In Information and Communication Technologies in Tourism 2017 (pp. 317-330). Springer, Cham.

Wu, J., Law, R., \& Liu, J. (2018). Co-creating value with customers: a study of mobile hotel bookings in China. International Journal of Contemporary Hospitality Management, 30(4), 2056-2074. https://doi.org/10.1108/IJCHM-08-2016-0476.

Yang, Y., Zhong, Z., \& Zhang, M. (2013). Predicting tourists decisions to adopt mobile travel booking. International Journal of u-and e-Service, Science and Technology, 6(6), 9-20. https://doi.org/10.14257/ijunesst.2013.6.6.02.

Zhou, T., Lu, Y., \& Wang, B. (2010). Integrating TTF and UTAUT to explain mobile banking user adoption. Computers in Human Behavior, 26(4), 760-767. https://doi.org/10.1016/j.chb.2010.01.013. 